\title{
PERANCANGAN APLIKASI E-RECRUITMENT BERBASIS WEB DENGAN NOTIFIKASI SMS GATEWAY DI PT. AGUNG KARUNIA UTAMA
}

\author{
Waliadi Gunawan', ${ }^{1}$ Ma'sum $^{2}$, Aang Rizkiyana ${ }^{3}$ \\ Fakultas Ilmu Komputer Universitas Banten Jaya \\ Jl. Ciwaru Raya II No. 73 Warung Pojok Kota SerangBanten \\ E-mail:waliadigunawan@unbaja.ac.id ${ }^{1}$,masum@unbaja.ac.id ${ }^{2}$, \\ aangrizkiyana@unbaja.ac.id ${ }^{3}$
}

\begin{abstract}
In this advanced technology, the need of information is needed in supporting the accurate, on time, and relevant information, The information got from the process of a system of information. Thereforem a company needs a computerized system of information. It began with the efforts of PT. Telekomunikasi Indonesia to have a partnership in the field of telecommunication. Thus, PT. Agung Karunia Utama was chosen as one of the contracted partners in the form of letter of partnership.In recruiting that is in collecting application files sent by the applicants that are selected in the form of documents that will take the time to select the files one by one continually, and it will make the obstacles in selecting the data of applicants. The candidates of applicant send the files of application in the form of hard copy used in administration selecting, then from the side of HRD should input the data of the candidates on by one into the database, so it need a longer time to the process of administration selection. With the advanced IT, e-recruitment by using company website as the effective method. Since it gives the opportunities to know more about the company only but it also can give the detailed descriptionabout the offered job. The using of $e$ recruitment helps the company to run the process of recruitment that is fast, effective and resulting consistently.
\end{abstract}

Keywords : E-recruitment, Telecommunication

\section{PENDAHULUAN}

Di tengah perkembangan teknologi yang sangat pesat saat ini, kebutuhan akan informasi sangat dibutuhkan dalam menunjang informasi yang akurat, tepat waktu, dan relevan. Informasi didapatkan dari pengolahan suatu sistem informasi. Oleh sebab itu, suatu perusahaan membutuhkan sistem informasi yang terkomputerisasi.

Berawal dari upaya PT. Telekomunikasi Indonesia untuk melibatkan Mitra kerja yang bergerak di bidang telekomunikasi. Maka dari itu PT. Agung Karunia Utama dipilih sebagai salah satu mitra yang di kontrak dalam bentuk Perjanjian Kerja Sama (PKS). Perusahaan ini bergerak di bidang usaha Jasa dan Konstruksi Jaringan Telekomunikasi, untuk pekerjaan pengadaan, pemeliharaan serta 
pengolahan jaringan akses. Kerja sama ini juga bertujuan untuk membantu program pemerintah untuk menyerap tenaga kerja khususnya di daerah Serang Banten yang mempunyai keahlian terutama berhubungan dengan mekanikal dan elektrikal telekomunikasi.

Dalam proses perekrutan tenaga kerja masih menggunakan sistem manual sehingga sulit dalam mengolah data pegawai. Hal yang dimaksud adalah dalam proses pengumpulan berkas lamaran yang dikirim pelamar yang akan diseleksi dalam bentuk dokumen yang pastinya akan membutuhkan waktu yang lama untuk menyeleksi berkas tersebut satu persatu secara berkala, dan akan terjadinya penumpukan data pelamar. Calon pelamar mengirimkan berkas lamaran berupa hard copy yang digunakan dalam seleksi administrasi, kemudian dari pihak Sumber Daya Manusia (SDM) atau Human Resource Development (HRD) harus menginputkan data calon pelamar tersebut satu per satu ke dalam database mereka sehingga membutuhkan waktu yang lama untuk proses seleksi administrasi. Oleh karena itu dibutuhkan suatu aplikasi yang dapat meningkatkan efektifitas dan efisiensi dalam proses rekrutmen.

Pada saat ini, telah banyak perusahaan yang menggunakan kecanggihan teknologi dalam proses rekrutmen dan seleksi. Sejalan dengan perkembangan IT, $e$ recruitment dengan menggunakan website perusahaan dianggap sebagai metode yang paling efektif. Selain tidak hanya mendapat kesempatan untuk mengenal lebih dekat perusahaan sebelum wawancara, tapi juga mendapat gambaran yang detail mengenai pekerjaan yang ditawarkan. Penggunaan e-recruitment sangat membantu perusahaan menjalankan proses rekrutment yang cepat, efektif dan secara konsisten menghasilkan.

\section{METODE PENELITIAN}

Teknik pengumpulan data pada lokasi penelitianadalah dengan cara pengamatan (observasi) dan juga wawancara (interview)

a) Pengamatan (observasi) yaitu mengadakan peninjauan langsung terhadap kegiatan dan sistem yang sedang berjalan 
b) Wawancara (interview) yaitu penelitian dilakukan dengan cara mengadakan tanya jawab langsung dengan pegawai serta dengan pihak berwenang yang ada di PT. Agung Karunia Utama.

Setelah melakukan penelitian dan menganalisa sistem informasi $e$ recruitment karyawan yang berjalan di PT. Agung Karunia Utama dan kegiatan yang berhubungan dengan penerimaan karyawan baru, maka analisis dari $e$ recruitment yang berjalan adalah mulai dari merekrut karyawan sesuai persyaratan perusahaan, seleksi administari, tes seleksi kemampuan, dan tes wawancara hingga pada informasi karyawan yang lulus seleksi dan gugur seleksi.

\section{HASIL DAN PEMBAHASAN}

Sistem yang telah dibuat akan mengalami uji coba pada PT. Agung Karunia Utama dan hasil uji coba semoga sesuai dengan yang di harapkan serta bermanfaatbagi para pengguna.

\section{Prosedur Oprasional}

Dalam mengoperasikan aplikasi e-recruitment ini harus mengikuti prosedurprosedur sebagai berikut :

\section{1) Login}

Form login adalah proses untuk mengakses sistem informasi dengan identitas dari akun pengguna dan kata sandi guna mendapatkan hak akses menggunakan aplikasi Untuk melakukan log masuk kesistem biasanya membutuhkan akun pengguna, digunakan sebagai identitas berupa runtutan karakter yang secara unik merujuk kepengguna tertentu. Kata sandi runtutan karakter berupa kunci yang dijaga kerahasiaannya terhadap orang lain.kedua pasang runtutan karakter itu harus tepat dan keduanya adealah pasangan yang tidak bisa dipasangkan. Kata sandi dapat berubah sesuai dengan kebutuhan, sedangkan akun penggunaan tidak pernah diubah karena berupa identitas unik yang merujuk kepengguna tertentu.

Dalam mengoperasikan Aplikasi Layanan Elektronik Dengan Notifikasi SMS Gateway harus mengikuti prosedur sebagai berikut :

1. Nyalakan komputer sesuai dengan standar yang telah ditentukan 
2. Pastikan aplikasi Xampp versi 1.8.1 telah terinstal dan berjalan

3. Aktifkan service gammuBuka web browser, ketikan di kotak alamat web dengan mengetikan http://localhost/aang

4. Setelah ditekan enter, maka akan muncul sebuah halaman Log In yang memiliki username dan password

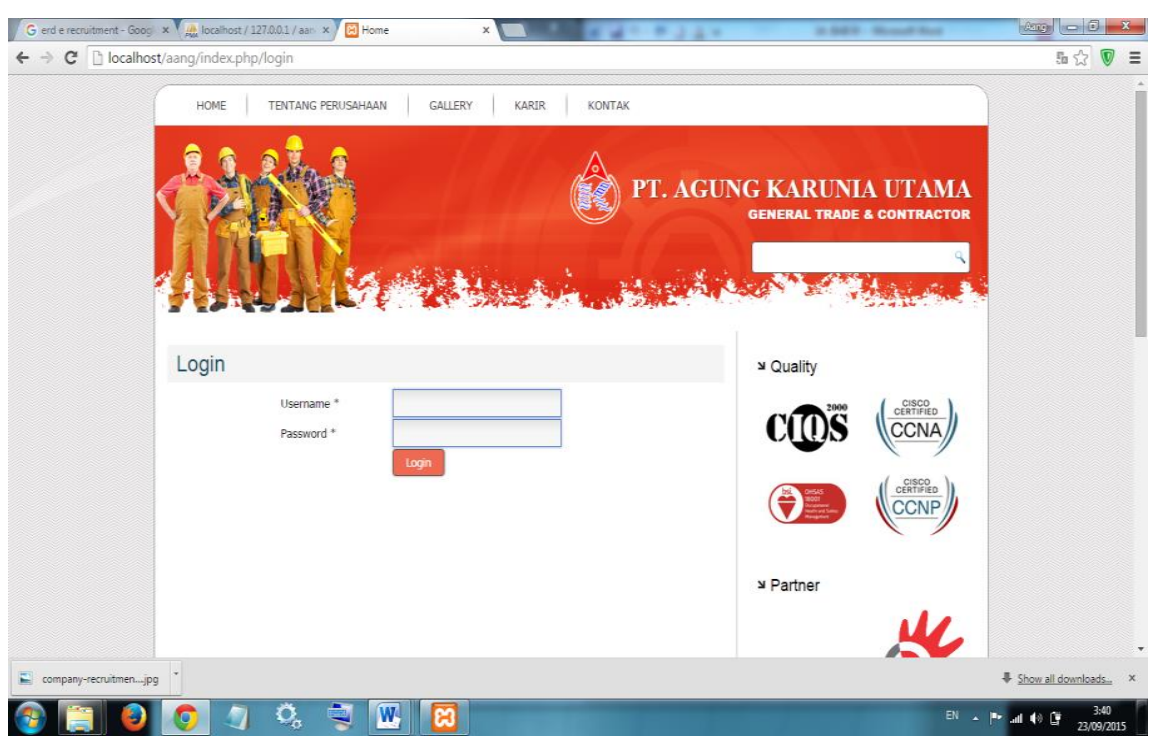

Gambar 1. Tampilan Aplikasi Menu Log In

2) Menu Utama Admin

Menu utama digunakan untuk mengakses seluruh fasilitas dari sistem aplikasi, terdiri dari menu utama yaitu menu master, lowongan, pegawai, pelamar, serta laporan. Untuk menampilkan form data klik pada judul seb menu yang tertera di menu.

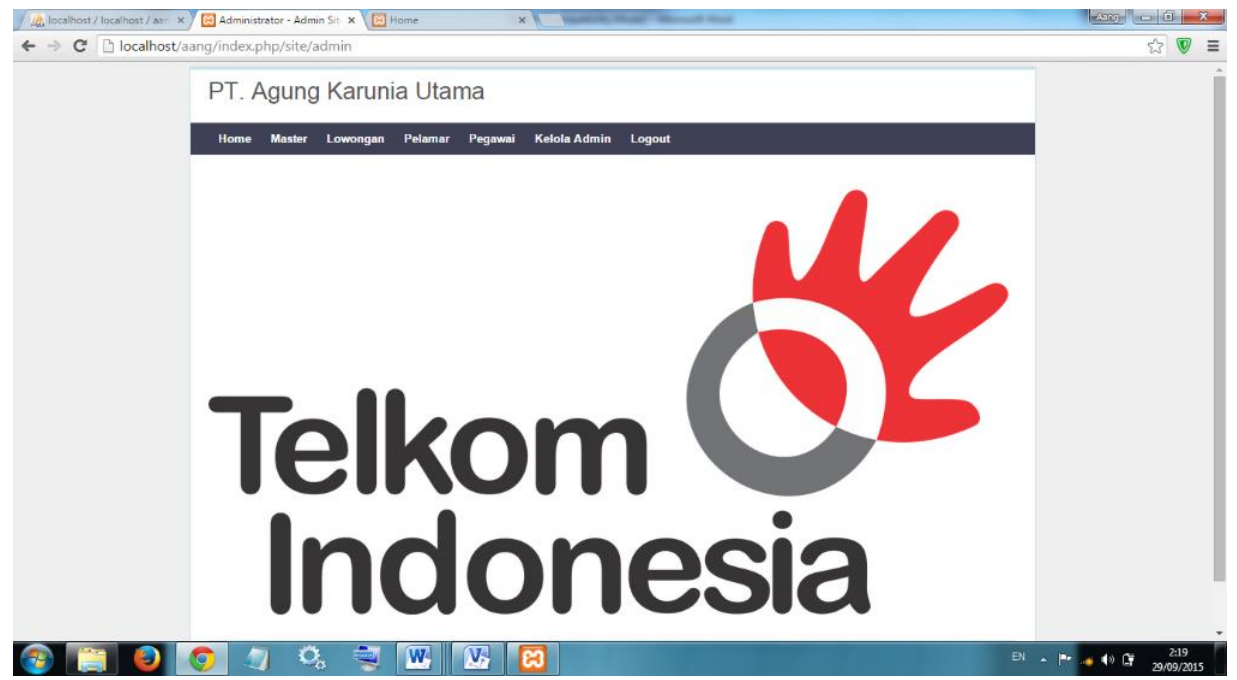

Gambar 2. Tampilan Aplikasi Menu Home Admin 
a). Sub Menu Kelola Psikotes

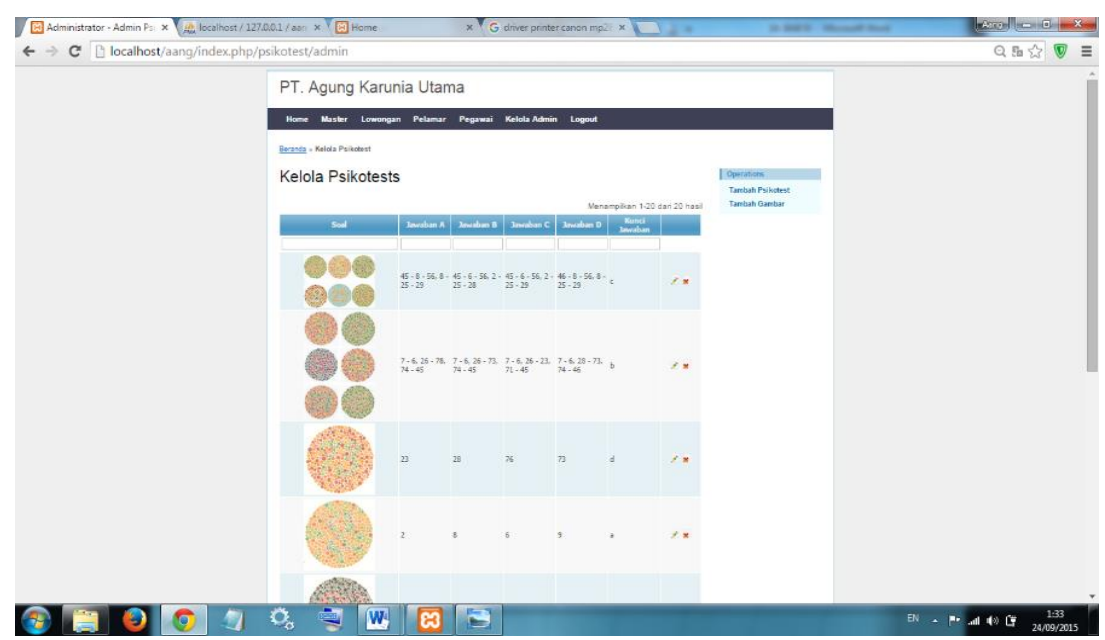

Gambar 3. Tampilan Aplikasi Admin Kelola Psikotes

b). Sub Menu Wawancara

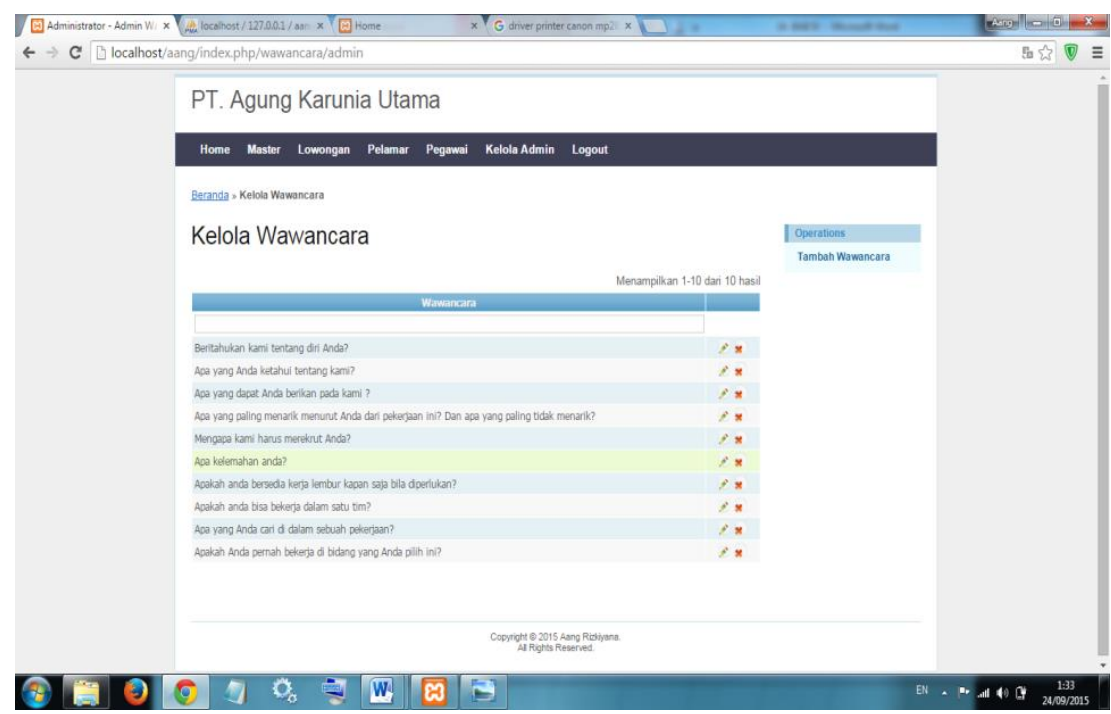

Gambar 4. Tampilan Aplikasi Admin Menu Wawancara 
c). Sub Menu Wawancara

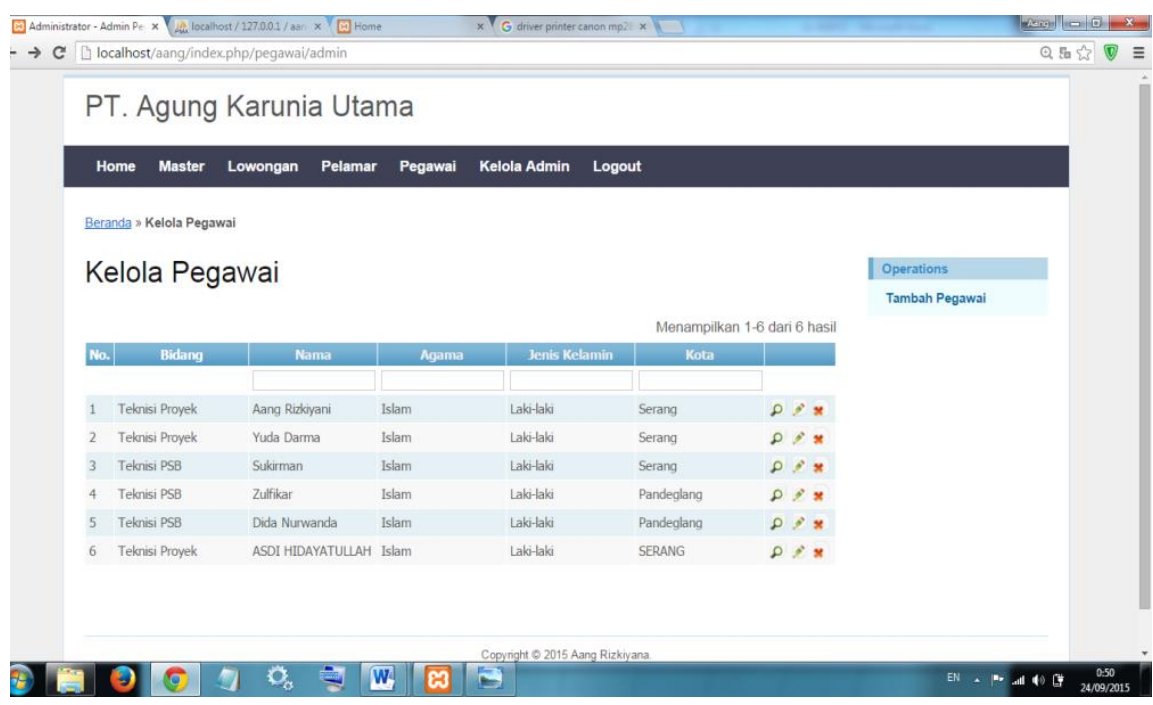

Gambar 5. Tampilan Aplikasi Admin Kelola Pegawai

3) Menu Data Diri Pegawai

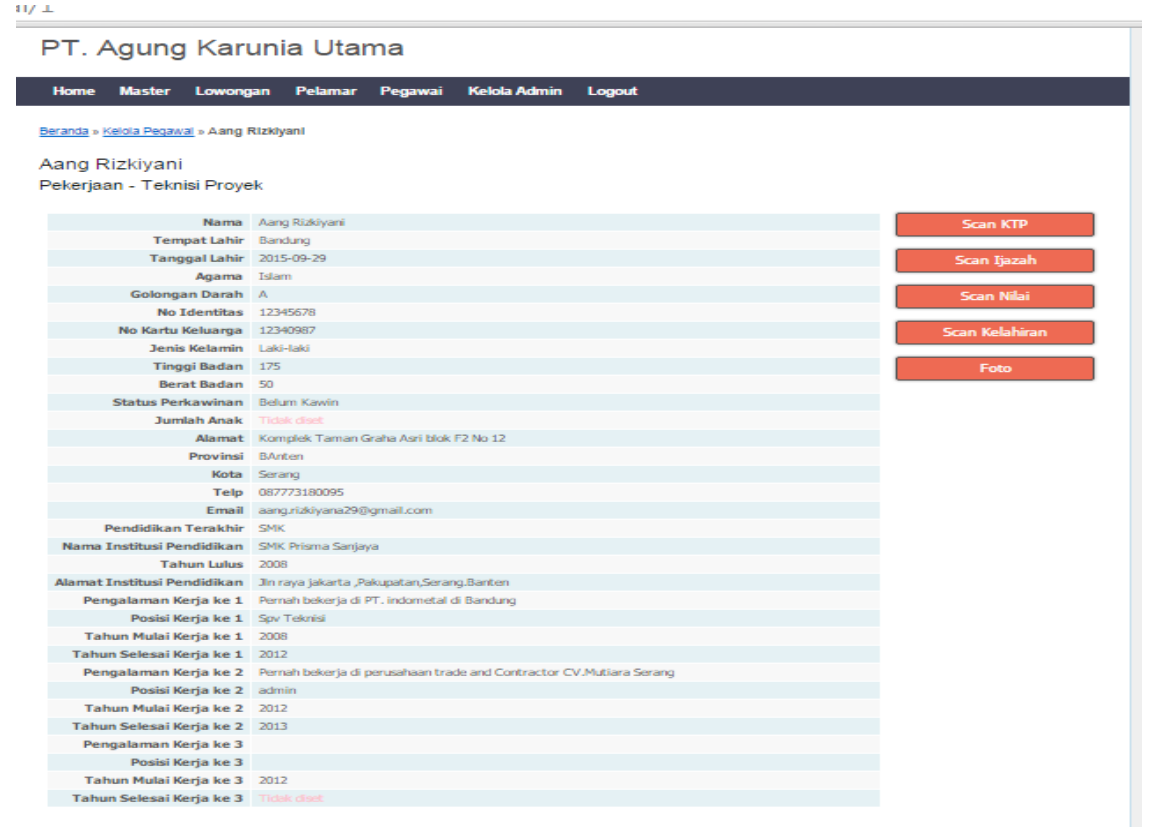

Gambar 6. Tampilan Aplikasi Admin Data Diri Pegawai 


\section{4) Menu Untuk Daftar Pelamar}

Untuk pelamar yang akan bergabung, pemar cukup membuka menu karir kemuadian lihat informasi pekerjaan yang ada di menu karir apakah sedang membutuhkan karyawan atau tidak. Apabila ada lowongan sesuai dengan yang kita inginkan pelamar tinggal menggeser crusor dan arahkan pada tombol bergabung, kemudian akan munculah menu selanjutnya yaitu menu data diri pelamar.

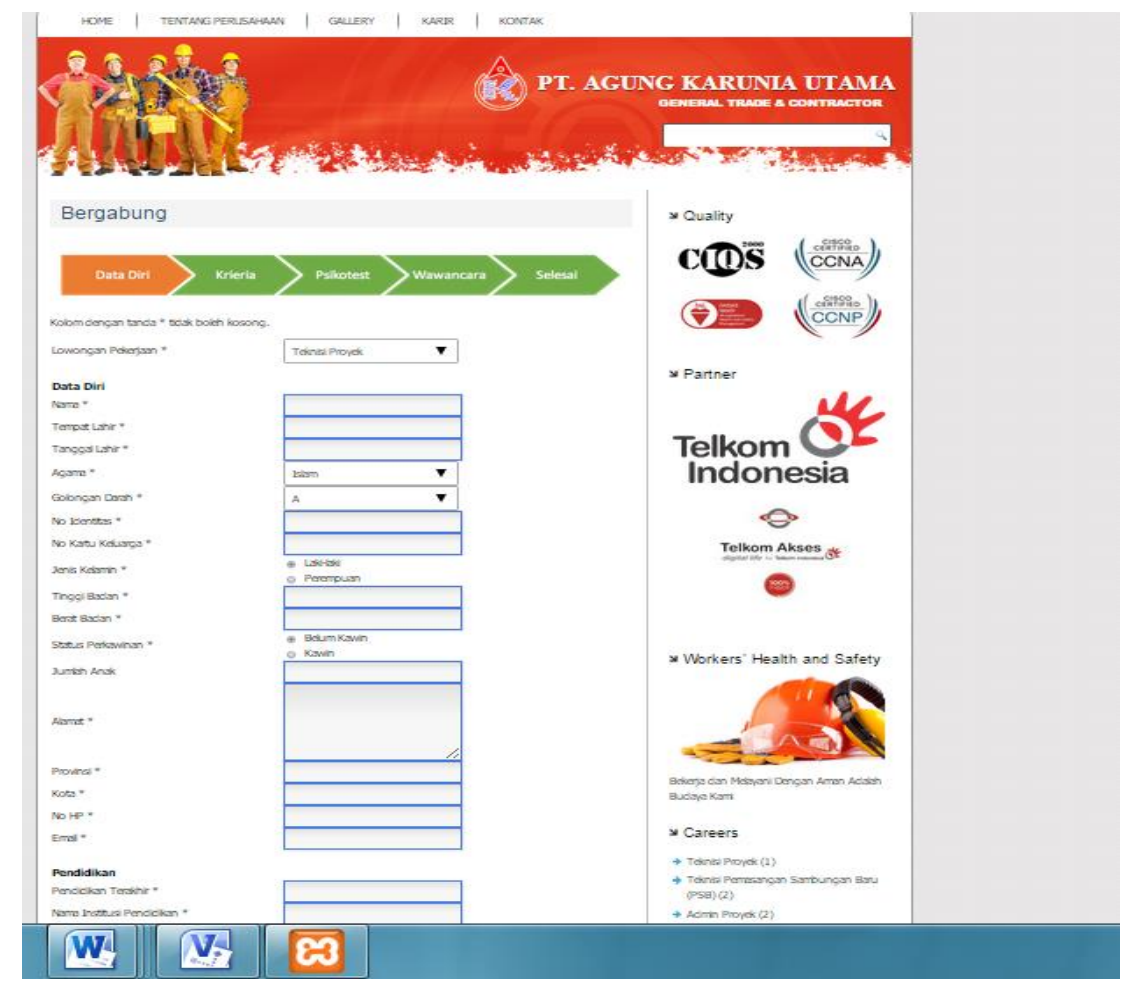

Gambar 7. Tampilan Aplikasi Menu Daftar Pelamar

Pelamar yang akan mendaftar diwajibkan mengisi semua kolom data diri, kemudian diwajibkan untuk scan KTP, Izajah, Nilai serta foto. Setelah itu "klik" tombol "selanjutnya", maka akan muncul pertanyaan mengenai kriteria. 


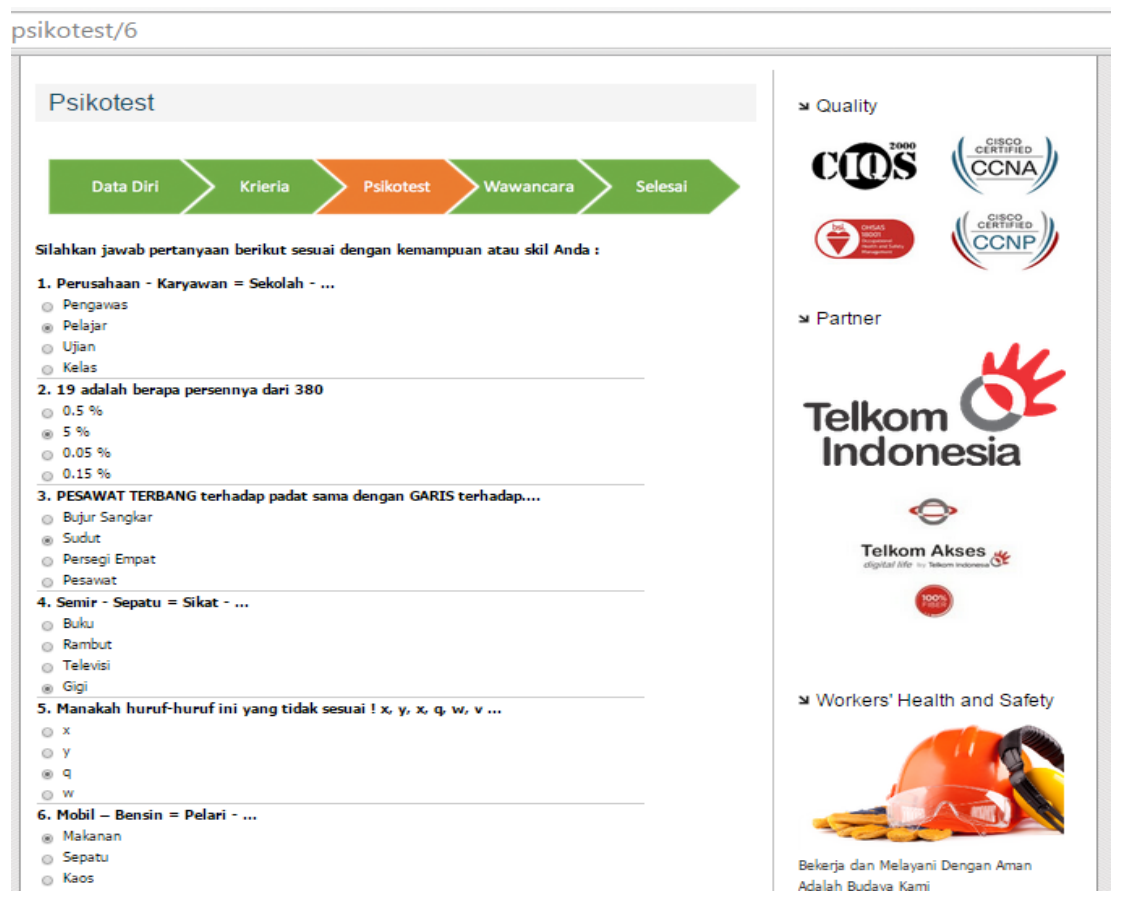

Gambar 8. Tampilan Aplikasi Menu Soal Tes Psikotes

Setelah selesai klik tombol “ selanjutnya” kemudian akan muncul menu wawancara.pelamar harus mengisi dengan benar sesuai dengan pertanyaan yang diberikan.

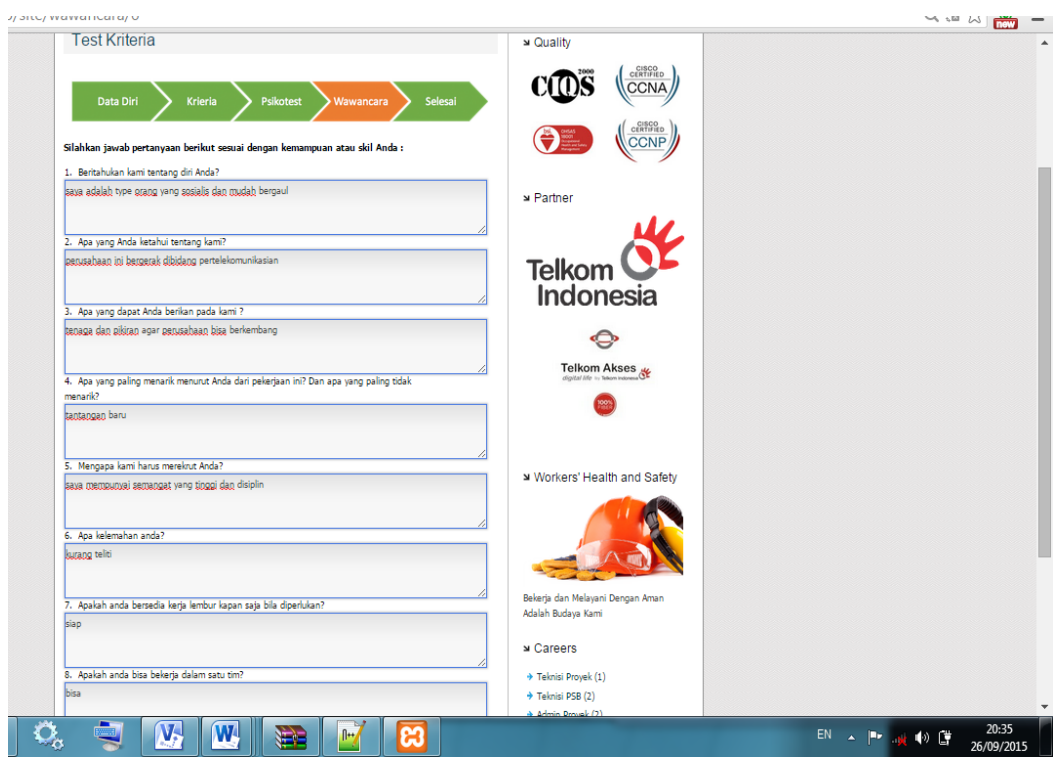

Gambar 9

Tampilan Aplikasi Menu Tes Wawancara 
Setelah selesai klik tombol "selanjutnya" maka akan muncul menu selesai dimana proses pelamaran telah berhasil dilaksanakan.

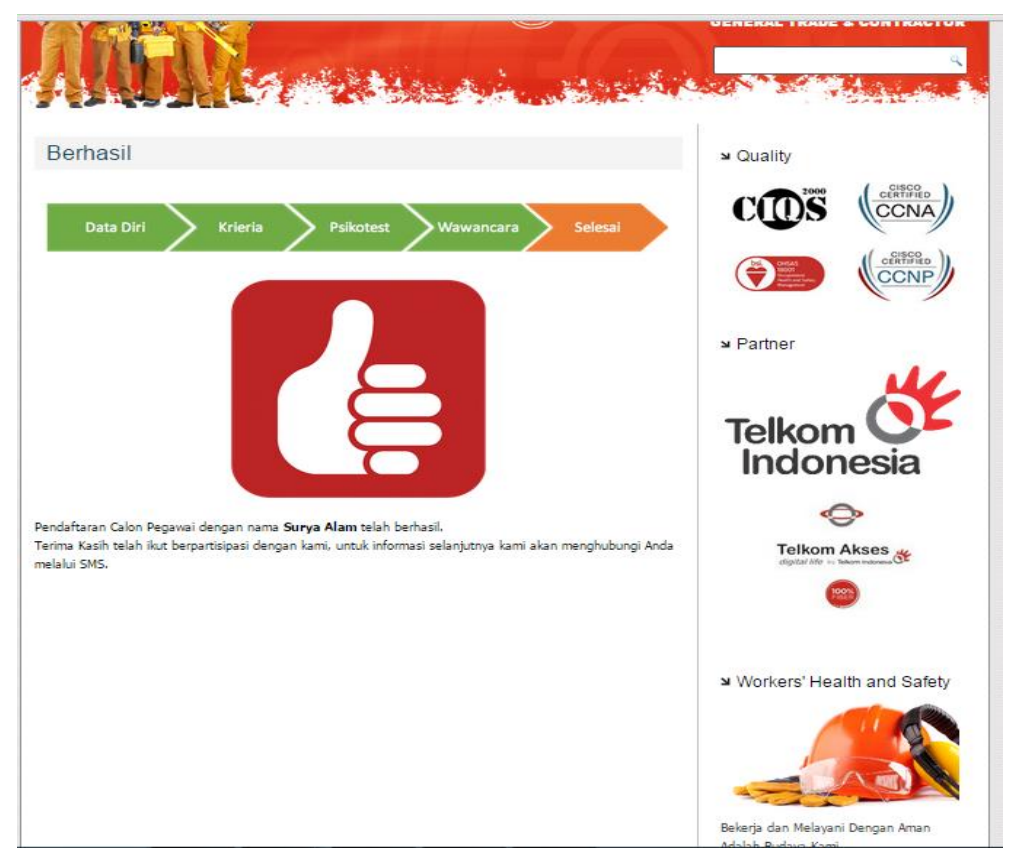

Gambar 10. TampilanAplikasi Proses Lamaran Berhasil

\section{KESIMPULAN}

Berdasarkan hasil uraian yang telah dikemukakan oleh penulis, maka dapat disimpulkan :

1. Dengan mengimplementasikan aplikasi e-recruitment berbasis web dengan notifikasi sms gateway ini bisa lebih mudah dalam mengatasi kebutuhankebutuhan dalam proses perekrutan pegawai.

2. Aplikasi e-recruitment dapat membantu pekerjaan sumber daya manusia khususnya HRD dalam mengambil keputusan untuk menerima atau menolak pelamar sesuai dengan kebutuhan dan skill yang dimiliki.

3. Aplikasi e-recruitment di harapkan mampu membantu pelamar dalam proses pendaftaran pegawai dan pemberian informasi mengenai perusahaan.

\section{DAFTAR PUSTAKA}

Al Fatta, Hanif, 2007, Analisa dan Perancangan Sistem Untuk Keunggulan Bersaing Perusahaan dan Organisasi Modern. Yogyakarta : Andi Offset.

AndiKoniyo, Kursini, 2007, Tuntunan Praktis Membangun Sistem Informasi Akuntansi dengan Visual Basic dan SQL Server. Yogyakarta : Andi Offset. 
Andri dan Kursini, 2007, Tuntunan Praktis Membangun Sistem Informasi Akuntansi denan Visual Basic dan Microsoft SQL Server, Yogyakarta : Penerbit Andi.

Anhar, 2010, Panduan Menguasai PHP dan MySQL Secara Otodidak. Jakarta : Media kita.

Dewobroto, Wiryanto., 2005, Aplikasi Rekayasa Konstruksi dengan Visual Basic 6.0 . Jakarta : PT. Elex Media Komputindo.

H.M. Jogiyanto, Analisa dan Sistem Informasi Pendekatan Terstruktur Teori dan Praktek Aplikasi Bisnis. Yogyakarta : Penerbit Andi.

Hall, James A., 2007, Sistem Informasi Akuntansi. Jakarta : SalembaEmpat.

Hartono, Jogiyanto, 2005, Analisis dan Design. Yogyakarta : Andi Offset.

http://www.kamusbesar.com/27297/notifikasi, 08/05/2015

Kadir, Abdul, 2004, Pengenalan Sistem Informasi.Yogyakarta : Andi Offset., 2009, Mudah Menjadi Programer PHP. Yogyakarta : Andi Offset

Kurniawan, Yahya, 2005, Kiat Praktis Menguasai Action Script 2.0 Flash MX 2004. Jakarta : PT. Elex Media Komputindo

Kursini, 2007, Strategi dan Perancangan Basis Data.Yogyakarta: Andi Offset.

Sadeli, Muhammad, 2012, Aplikasi SMS dengan Visual Basic 6.0 dan Visual Basic 2010. Pelembang : Maxikom.

Sakur, Stendy B, 2010, PHP 5 Pemrograman Berorientasi Objek - Konsep dan Imlementasi. Yogyakarta : Andi Offset.

Santoso, Harip, 2006, Membuat Database pada SQL Server 2000 Menggunakan VB. 6.Jakart : PT. Elex Media Komputindo.

Soeherman, Bonie.,dan Pinontoan, 2008, Designing Information System. Jakarta : PT Elex Media Komputindo.

Marihot Tua Efendi Hariandja, 2007, Manajemen Sumber daya manusia, Jakarta: Grasindo. 